\title{
Liberdade, dignidade e emancipação: o sentido da educação em direitos humanos em Paulo Freire
}

\section{Carlos Eduardo Oliveira Dias}

cceod@usp.br

Mestre em Direito do Trabalho pela PUC-

SP. Doutorando em Direito do Trabalho pela Universidade de São Paulo (USP). Juiz Titular da 1a. Vara do Trabalho de Campinas/SP. Membro da Associação Juízes para a Democracia (AJD) e do Instituto de Pesquisas e Estudos Avançados da Magistratura e do Ministério Público do

Trabalho (IPEATRA)

Recebido em 26/08/2011

Aprovado em 23/02/2012

\section{Resumo}

O presente artigo apresenta uma compilação de ideias e de conceitos de Paulo Freire, procurando identificar no educador uma antevisão dos compromissos contemporâneos da Educação em Direitos Humanos. Embora não estivesse plenamente conformados em sua época, as manifestações estruturais de sua doutrina se enquadram perfeitamente nas perspectivas dos Planos Nacional e Internacional de Educação em Direitos

Humanos, consagrados após sua morte, mormente sua concepção de ser humano, que é qualificado por ele como sendo um ser inacabado, inconcluso, que tem a vocação natural de ser mais, que representa lutar pela sua própria dignidade.

\section{Palavras-chave}

Paulo Freire. Direitos Humanos. Educação. Plano Nacional de Educação em Direitos Humanos. Dignidade. 


\section{Freedom, dignity and empowerment: the meaning of Human Rights Education in Paulo Freire}

\section{Carlos Eduardo Oliveira Dias}

\section{Abstract}

This paper compiles ideas and concepts developed by a Brazilian educator, Paulo Freire, as it highlights that the Freirean doctrine in Human Rights Education, even though not entirely in line with structural manifestations seen at his time, are still perfectly aligned with Brazil's current National and International Human Rights Action Plans. Known worldwide for his advocacy of education for critical consciousness, and in a pedagogy of liberation, Mr. Freire believed that all buman beings should be active participants and not passive consumers in society. In teaching literacy, be wanted to generate among his students what he called "a critical comprehension of reality." $M r$. Freire refined his education methods beginning in the late 1950's during literacy campaigns among peasants in the poverty-stricken northeast of Brazil and propounded them in his best-selling 1970 book, 'Pedagogy of the Oppressed.'
Key words

Paulo Freire, Human Rights, National and International Human Rights Plans, Dignity 


\section{Sumário}

Introdução

1 Educar em Direitos Humanos: um desafio da pós-modernidade

2 Os direitos humanos no Brasil: uma preocupação tardia

3 Criticização e problematização: o sentido freiriano de educação

4 À guisa de conclusão: há educação em direitos humanos em

Paulo Freire?

Referências Bibliográficas 


\begin{abstract}
"A existência humana não pode ser muda, silenciosa, nem tampouco pode nutrir-se de falsas palavras, mas de palavras verdadeiras, com que os homens transformam o mundo. Existir, humanamente, é pronunciar o mundo, é modificá-lo. O mundo pronunciado, por sua vez, se volta problematizado aos sujeitos pronunciantes, a exigir deles novo pronunciar. Não é no silêncio que os homens se fazem, mas na palavra, no trabalho, na ação-reflexão."
\end{abstract}

Paulo Freire

"Numa terra de fugitivos, aquele que anda na direção contrária parece estar fugindo.”

T.S. Eliott

\title{
Introdução
}

Paulo Freire ${ }^{1}$ nasceu no Recife em setembro de 1921 e, mesmo com dificuldades, tornou-se professor aos 21 anos de idade, no colégio onde estudara. Em 1959, com a tese Educação e atualidade brasileira, obteve o título de doutor em Filosofia e História da Educação. Formado em direito, desistiu da advocacia e tornou-se educador, por clara influência de sua mulher, Elza, que também era professora. Participou da criação do Movimento de Cultura Popular do Recife, em 1960, sendo designado para presidir a Comissão Nacional de Cultura Popular do Ministério da Educação, em 1963, coordenando o Programa Nacional de Alfabetização.

Com o Golpe de 64, foi preso, perseguido e constrangido com sucessivos Inquéritos Policiais Militares, eis que era considerado "subversivo", em função de sua atitude política de alfabetizar e educar a partir da conscientização. Exilou-se, inicialmente na Bolívia, que deixou após outro golpe, fixando-se no Chile. Nos cinco anos que ali esteve, realizou importantes projetos de alfabetização dos camponeses daquele país, ressoando a criação das suas principais obras: Educação como prática da liberdade e Pedagogia do oprimido, em que foram lançados os principais

1 As principais informações dessa síntese biográfica foram colhidas de FREITAS, Marcos Cezar de e BICCAS, Maurilane de Souza. História Social da Educação no Brasil (1926-1996). Vol. 3. São Paulo : Cortez, 2009, e de FREIRE, Lutgardes Costa. "Paulo Freire por seu filho". SOUZA, Ana Inês (org.). Paulo Freire - Vida e obra. 2ed Edição. São Paulo: Expressão Popular, 2010, p. 305-318, que nos premia com uma deliciosa bibliografia de seu pai, em um tom naturalmente amoroso e afetivo. 
fundamentos de suas teorias educacionais, já implementadas desde o início da década. Sua obra o tornou conhecido, e o fez receber um convite para ser Professor Convidado na Universidade de Harvard (EUA) e outro para ser Consultor Especial do Departamento de Educação do Conselho Mundial de Igrejas, em Genebra. Nessa atividade peregrinou por diversos países da América, da Ásia e da África, disseminando o trabalho que o celebrizou, de alfabetização de adultos a partir da lógica da educação como prática conducente à liberdade. ${ }^{2}$

Isso revela mais uma latente contradição da história brasileira: um de seus intelectuais mais importantes tornou-se famoso por seu trabalho realizado no exterior, e ele só veio a exercê-lo de forma intensa e coordenada em seu país a partir de seu retorno do exílio. ${ }^{3}$ Assim, tirante as breves experiências realizadas no início dos anos 1960 - que foram a gênese de toda a sua pedagogia -, seus projetos só puderam ser amplificados e efetivamente implementados com o ocaso da ditadura, que além de banir Paulo Freire da convivência com seus confrades, ainda prejudicou a disseminação de suas práticas e de sua teoria, exilada da influência intelectual dos educadores, como a de tantos outros autores de grande relevância.

A despeito de haver no Brasil uma preocupação demasiado tardia com os direitos humanos e com a educação em direitos humanos, isso não impediu que um dos principais educadores brasileiros estruturasse toda a sua teoria - ou método, como preferem alguns - fundada nos pressupostos de valorização da dignidade da pessoa humana e na aquisição da plena cidadania. Ainda que não falasse, propriamente, em direitos humanos, toda a construção freireana a respeito de métodos de educação, especialmente em adultos sem alfabetização formal, foi balizada no sentido de alcançar pelo menos três objetivos fundamentais: a liberdade, a dignidade e a emancipação das classes oprimidas. É esse trinômio que tentaremos explorar para identificar o sentido da educação em direitos humanos para Paulo Freire, o que constitui a finalidade deste trabalho.

2 Tanto assim que esse é o título de um dos seus principais livros. A propósito, no prefácio desse trabalho, Weffort aponta que essa expressão é menos um axioma do que um desafio da história presente; "Quando alguém diz que a educação é a afirmação da liberdade e toma as palavras a sério - isto é, quando as toma por sua significação real - se obriga, neste mesmo momento, a reconhecer o fato da opressão, do mesmo modo que a luta pela libertação." WEFFORT, Francisco C. Educação e política - Reflexões sociológicas sobre uma pedagogia da Liberdade. Educação como prática da liberdade - prefácio. Rio de Janeiro : Paz e Terra, 1989, p. 7

3 Com a Lei da Anistia, retornou ao Brasil em 1979, tornando-se professor da Unicamp e da PUC de São Paulo, sendo, ainda, Secretário de Educação do Município de São Paulo entre 1989 e 1991 


\section{Educar em Direitos Humanos: um desafio da pós-modernidade}

Sob o signo da chamada modernidade, a humanidade encontrou fundamentos estruturais para justificar o cometimento sistemático de algumas das piores atrocidades da história. Não que, antes dela, não se vivessem momentos de barbárie; muito pelo contrário. $\mathrm{O}$ que a distingue, no entanto, nesse ranking macabro, é que boa parte dessas condutas foram filosoficamente sustentadas por ideais conformados com o objetivo de reformular as relações sociais, políticas e econômicas na Europa - depois estendendo-se para o restante do planeta - a partir da superação do medievalismo e toda a sua carga dita retrógrada e estagnadora. ${ }^{4}$

Em outro sentido, não se pode deixar de reconhecer que as principais conquistas em termos de direitos humanos foram legadas ao longo da modernidade, mormente a partir da Declaração de 1789. A despeito de ser fundada apenas na perspectiva formal do conceito de igualdade, e valorizar a liberdade somente em sua percepção individualista ${ }^{5}$ é inegável que essa positivação teve fundamental importância na conformação das demais gerações de direitos humanos e na inserção constitucional de dispositivos de proteção em boa parte dos Estados. ${ }^{6}$

De outra parte, somente depois do genocídio cometido por regimes totalitários em meados do século XX, vimos a comunidade internacional dedicar uma intensa preocupação com a criação de mecanismos mais efetivos de proteção aos direitos humanos. É indiscutível que a experiência mundial durante a $2^{a}$. Guerra foi um marco fundamental para o processo de reconstrução desses direitos. ${ }^{7}$ Afinal, as práticas verificadas no Holocausto definiram uma concreta ruptura com quaisquer paradig-

4 BITTAR, Eduardo Carlos Bianca. O Direito na Pós-Modernidade. 2ed. Rio de Janeiro : Forense Universitária, 2009.

5 Em tal contexto, MOREIRA, Vital. O Futuro da Constituição. GRAU, Eros e GUERRA FILHO, Willis Santiago (orgs.). Direito Constitucional - Estudos em homenagem a Paulo Bonavides. São Paulo : Malheiros, 2001, p. 314-315 aponta que essa concepção típica do Estado Liberal burguês, preconizava a "redução do Estado às tarefas de garantia da liberdade e da segurança, na participação política reservada à burguesia, na separação Estado/sociedade, na administração dedicada às tarefas de ordem pública e de polícia, na economia entregue à autoregulação do mercado."

6 É a mesma análise de BITTAR, Eduardo Carlos Bianca. O Direito na Pós-Modernidade. 2ed. Rio de Janeiro : Forense Universitária, 2009, p. 284: "Isto permite dizer que, se são historicamente construídos, se foram sistematizados e positivados pelo movimento positivista liberal de direito, se foram trivializados com a paulatina transformação do próprio jusnaturalismo em juspositivismo no constitucionalis contemporâneo, com a consequente descartabilidade de seus textos, isto não afasta o seu caráter paradigmático na busca de soluções razoáveis para a orientação dos direitos vigentes em sociedade."

7 Inevitável, nesse contexto, o resgate da percepção de, nos dizeres de Arendt, não são um dado, mas sim uma invenção humana, em permanente processo de construção e reconstrução (ARENDT, 1979). 
mas de respeito aos direitos humanos, ao se permitir a classificação de determinados seres humanos como supérfluos e, dada a sua falta de relação com o mundo comum, restaram "excluídas de um repertório compartilhado de significados que uma comunidade política oferece e que a cidadania garante." ${ }^{8}$ Dolorosamente, da tragédia extraímos a demarcação histórica no sentido da internacionalização dos direitos humanos. ${ }^{9}$

A realidade pós-moderna, no entanto, recebe como legado a incumbência de promover uma "permanente reflexão sobre a sua incapacidade de tornar efetivos tais direitos", visto que, embora sejam "constitutivos de obrigações mínimas em face do Estado" e "limitadores antiarbitrários", certamente não são "suficientes por si mesmos". ${ }^{10}$ É sintomático que o conjunto de fenômenos que se qualificam como pós-modernos tenham sido construídos a partir da "grande recaída a que o projeto moderno conduziu a humanidade, seguindo o pensamento de Adorno". ${ }^{11}$ No entanto, em que pese constitua a crítica da modernidade e o reconhecimento da emergência de outra perspectiva de se compreender o mundo, a pós-modernidade representa a "simplificação conceitual das tensões e contradições (...) da condição humana hodierna, que abalou o projeto da modernidade, sem necessariamente superá-lo completamente". ${ }^{12}$

8 LAFER, Celso. A reconstrução dos direitos humanos. São Paulo : Companhia das Letras, 1999. A citação de Hannah Arendt também é do livro já mancionado, parte II.

9 Como ensina Louis Henkin, citado por PIOVESAN (2006, p. 7): "O Direito Internacional pode ser classificado como o Direito anterior à $2^{\text {a }}$. Guerra Mundial e o Direito posterior a ela. Em 1945, a vitória dos aliados introduziu uma nova ordem com importantes transformações no Direito Internacional." A autora também observa que "se a Segunda Guerra significou a ruptura com os direitos humanos, o Pós-Guerra deveria significar sua reconstrução.” (Idem, p. 9)

10 BITTAR, Eduardo Carlos Bianca. O Direito na Pós-Modernidade. 2ed. Rio de Janeiro : Forense Universitária, 2009, pp. 284-285

11 BITTAR, Eduardo Carlos Bianca. O Direito na Pós-Modernidade. 2ed. Rio de Janeiro : Forense Universitária, 2009, pp. 145-146

12 BITTAR, Eduardo Carlos Bianca. O Direito na Pós-Modernidade. 2ed. Rio de Janeiro : Forense Universitária, 2009, p. 146. Em sentido similar vai a conclusão de HARVEY, David. Condição pós-moderna. São Paulo : Loyola, 2001, p.111, que afirma que "há mais continuidade do que diferença entre a ampla história do modernismo e o movimento denominado pós-modernismo". No entanto, a despeito dessa confluência, o autor é feroz crítico desse consenso que resultou na afirmação do conceito simplificador chamado de pós-modernidade. $O$ que nos interessa, no caso, é nos afastarmos da falsa ideia que, ao deparar perfunctoriamente com esses conceitos, tende a enxergar antagonismo latente no binômio modernidade/pósmodernidade. Ficamos com a conclusão de Agnes Heller que afirma que o pós-moderno é "uma nova atitude em relação à modernidade, uma compreensão da modernidade que difere das compreensões modernas anteriores". (Apud BITTAR, Eduardo Carlos Bianca. O Direito na Pós-Modernidade. 2ed. Rio de Janeiro : Forense Universitária, 2009, p. 146, nota 70). 
Em função disso, temos que, no plano da sociedade pós-moderna tem-se a nítida consciência de que a mera estipulação formal dos direitos humanos, desvinculada dos preceitos éticos e axiológicos, não é sustentável nem sequer do ponto de vista jurídico, eis que o Estado continua a dizimar preceitos garantidores desses mesmos direitos, seja em atitudes comissivas seja por sua omissão. ${ }^{13}$ Superado o momento da justificação e do reconhecimento institucional dos direitos humanos, o tema que se coloca à frente diz respeito a como se pode agir para garantir, promover e proteger esses direitos. O desafio da condição pós-moderna, portanto, é o da construção de modelos de atuação das sociedades que passem, necessariamente, pelos paradigmas da cidadania, única forma de se oferecer pleno acesso à ordem jurídica justa: é o direito de se ter direitos. ${ }^{14}$

Nesse contexto, é inegável que qualquer concepção contemporânea dos direitos humanos deve ter como foco "os conceitos de cidadania democrática, cidadania ativa e cidadania planetária”, com inspiração em valores huamanistas e fundadas "nos princípios a liberdade, da igualdade, da equidade e da diversidade, afirmando sua universalidade, indivisibilidade e interdependência". ${ }^{15}$

É desse desígnio que se compreende que o exercício da cidadania só é possível mediante a formação de cidadãos plenamente cientes e conscientes de seus direitos e deveres, constituindo-se efetivamente como sujeitos desses direitos, com capaci-

13 Daí a subsistência de inúmeras situações de violações de direitos humanos praticadas por diversos Estados nacionais, como a tortura, a prisão sem o devido processo legal, a prática de crimes de guerra; ao lado disso, em muitas nações reconhecidamente democráticas ainda se vê uma atuação muito tímida dos poderes constituídos no sentido de concretizar direitos fundamentais, como os relacionados à segurança, à saúde, à educação e a condições apropriadas de trabalho.

14 Nesse sentido, Lafer sintetiza o pensamento de Hannah Arendt: "O que Hannah Arendt estabelece é que o processo de asserção dos direitos humanos, enquanto invenção para a convivência coletiva, exige um espaço público. Este é kantianamente uma dimensão transcendental, que fixa as bases e traça os limites da interação política. A este espaço só se tem acesso pleno por meio da cidadania. É por essa razão que, para ela, o primeiro direito humano, do qual derivam todos os demais, é o direito a ter direitos, direitos que a experiência totalitária mostrou que só podem ser exigidos através do acesso pleno à ordem jurídica que apenas a cidadania oferece" LAFER, Celso. A reconstrução dos direitos humanos. São Paulo : Companhia das Letras, 1999, p. 166).

15 BRASIL, Comitê Nacional de Educação em Direitos Humanos. Plano Nacional de Educação em Direitos Humanos. Brasília : Secretaria Especial de Direitos Humanos; Ministério da Educação e Ministério da Justiça; UNESCO, 2006. Essa referência resgata dois elementos de suma importância, que evidencia o momento histórico da afirmação desse Plano. De um lado, suscita os preceitos fundantes dos direitos humanos reconhecidos na Convenção de Viena, como superação de uma equivocada visão hierarquizante que se tentou implementar como forma de atenuação de alguns aspectos desses mesmos direitos. De outra parte, invoca princípios que não são mais fundados no trinômio clássico da percepção moderna de direitos humanos (liberdade, igualdade, fraternidade), mas sim preceitos cunhados em momentos posteriores por autores como Zygmunt Bauman, p.ex. 
dade de protagonizar materialmente as diretrizes normativas que se destinam à sua proteção e de controlar democraticamente as ações do Estado. Permite-lhes, ainda, cônscios de sua condição humana e de seu papel perante a humanidade, a plena valorização do princípio da dignidade e de sua efetivação concreta no plano da realidade, além de respeitar os paradigmas da solidariedade internacional e a diversidade de outros povos. Isso só é possível de se alcançar quando se consegue sensibilizar e humanizar os agentes desse processo, não pelo conteúdo do aprendizado, mas principalmente pelos métodos usados, oferecendo-se-lhes meios e instrumentos para que possam enxergar no outro a sua humanidade. ${ }^{16}$

Em tal prisma é que se pode afirmar a relevância na instituição de políticas de educação em direitos humanos. Com efeito, educar em direitos humanos representa a formação de uma cultura de respeito à dignidade humana por meio da promoção e da vivência dos valores da liberdade, da igualdade, da justiça, da solidariedade, da diversidade, da cooperação, da tolerância e da paz. Dito de outro modo, educar em direitos humanos significa a criação, a valorização e o compartilhamento de conceitos, costumes, atitudes, hábitos e comportamentos que decorrem dos mesmos valores mencionados, de modo a transformá-los em práticas concretas nos diversos segmentos da sociedade.

Não por outras razões essa preocupação tem aparecido com frequência em documentos internacionais de proteção aos direitos humanos, como o Pacto Internacional sobre os Direitos Econômicos, Sociais e Culturais (art. 13); o Pacto Internacional sobre os Direitos Civis e Politicos (art. 2o., 2), além da própria Convenção de Viena, apenas para citarmos os de ordem geral. Demais disso, a ONU também instituiu, em dezembro de 1994, a Década das Nações Unidas para a Educação em matéria de Direitos Humanos, abrangendo o período de 1995 a $2004,{ }^{17}$ além de estabelecer, em sua 52a.

16 A esse propósito: "Um projeto de direitos humanos deve acima de tudo ser capaz de sensibilizar e humanizar, por sua própria metodologia, muito mais do que pelo conteúdo daquilo que se aborda através das disciplinas que possam formar o caleidoscópio de referenciais de estudo e que organizam a abordagem de temas os mais variados, que convergem para a finalidade última do estudo: o ser humano" (BITTAR, Educação e metodologia para os direitos humanos: cultura democrática, autonomia e ensino jurídico, 2007, p. 316)

17 Sobre as principais atividades e constatações a respeito dessa década, vide relatório indicado na bibliografia (COMISSÃO Nacional para as Comemorações do 50o. Aniversário da Declaração Universal dos Direitos do Homem. Educação em Matéria de Direitos Humanos e Tratados de Direitos Humanos. Lisboa: Gabinete de Documentação e Direito Comparado da Procuradoria Geral da República de Portugal, 2002) 
Sessão da Assembleia Geral (outubro/97), a instituição do Programa Mundial de Educação em Direitos Humanos (PMEDH) e seu respectivo Plano de Ação, contendo diretrizes para a formulação de planos nacionais de ação para a educação em direitos humanos. ${ }^{18}$

Por fim, em março de 2011, a Comissão de Direitos Humanos da ONU aprovou, em sua 16a. reunião, a Declaração das Nações Unidas sobre Educação em Direitos Humanos e Formação, na qual estipula, já em seu art. 1o., que "todo mundo tem o direito de conhecer, buscar e receber informações sobre todos os direitos humanos e liberdades fundamentais e deve ter acesso à educação em direitos humanos e à formação." No mesmo sentido, o artigo 20. aponta que a "educação em direitos humanos e da formação é essencial para a promoção do acesso universal, o respeito e a observância dos direitos humanos e liberdades fundamentais para todos, em conformidade com os princípios da universalidade, indivisibilidade e interdependência dos direitos humanos". Desde então, tem-se um diploma normativo específico, no plano internacional, com as diretrizes fundamentais para a implementação de sistemas de educação em direitos humanos, desvelando-se um caminho mais do que sólido para a edificação global de práticas sistemáticas nesse sentido.

\section{Os direitos humanos no Brasil: uma preocupação tardia}

No âmbito nacional, a percepção sobre a relevância temática dos direitos humanos foi obtida de maneira por demais tardia. A par da instabilidade política caracterizadora de sua breve história republicana, é certo que o empuxo causado pelas motivações verificadas no plano mundial, mormente na Europa, tardou a chegar por aqui. Embora as liberdades civis e políticas tivessem sofrido profundas má-

18 No art. $2^{\circ}$. do PMEDH estão apontados os objetivos balizadores do plano, na esteira do quanto já dito anteriormente. Conforme já explicitado, essa positivação tem um papel fundamental na articulação das políticas nacionais sobre o assunto, pois fomenta cada Estado não só a estruturar seus planos de ação de maneira consonante com as diretrizes gerais como também os estimula a inserir os mesmos conceitos em suas ordens constitucionais. As normas internacionais passam a ser um referencial constitucional global, como explica Canotilho: "Os direitos humanos articulados com o relevante papel das organizações internacionais fornecem um enquadramento razoável para o constitucionalismo global. (...) Por isso, o Poder Constituinte dos Estados e, consequentemente, das respectivas Constituições nacionais, está hoje cada vez mais vinculado a princípios e regras de direito internacional. É como e o Direito Internacional fosse transformado em parâmetro de validade das próprias Constituições nacionais (cujas normas passam a ser consideradas nulas se violadoras das normas do jus cogens internacional). (...) A abertura ao Direito Internacional exige a observância de princípios materiais de política e de direito internacional tendencialmente informador do Direito interno" (CANOTILHO, Joaquim José Gomes. Direito Constitucional e Teoria da Constituição. Coimbra : Almedina, 1998, p. 1.217) 
culas durante o período pós-Revolução de 1930 e no decorrer do Estado Novo, a sociedade brasileira não se viu suficientemente envolvida pelo debate a respeito do processo de institucionalização dos direitos humanos visto na Europa, já que "os modelos de desenvolvimento, suas consequências sociais, a inserção internacional do país - ocupavam grande parte das formulações teóricas e políticas". ${ }^{19}$. Assim, os principais debates nacionais eram contextualizados a partir da lógica do desenvolvimento econômico, sendo certo que era compreendido que os direitos ainda não assegurados pelo sistema seriam resultado imediato desse desenvolvimento, ${ }^{20}$ fundado em uma espécie de "aliança social" que contemplava os interesses da burguesia industrial, das classes médias e dos trabalhadores sindicalizados. ${ }^{21}$

O incipiente processo democrático consubstanciado a partir de 1946 foi logo interditado pelo Golpe de 1964, que rompeu com o modelo existente e instaurou nova ditadura no país. No entanto, desta feita, o regime não apenas se limitava a suprimir as liberdades e garantias individuais e coletivas, mas também se caracterizou pela opressão econômica e social, mediante a limitação às negociações salariais. ${ }^{22}$ Com isso, a violência cometida pelo regime trouxe a questão dos direitos humanos para o centro do debate: sem qualquer expectativa de amplificação de direitos de ordem social, tornaram-se evidentes as práticas repressivas das liberdades civis, como a intervenção nas entidades sindicais e estudantis, a prisão de seus líderes, a implantação de censura nos meios de comunicação e, naturalmente, a prática da tortura e assassinato de centenas de opositores ao regime. O escancaramento das práticas violadoras cometidas pela ditadura serviram como estopim para que a luta pela democratização trouxesse em seu bojo o reconhecimento institucional da premência dos direitos fundamentais.

19 SADER, Emir. Contexto histórico e educação em direitos humanos no Brasil: da ditadura à atualidade. SILVEIRA, Rosa Maria Godoy et al. Educação em Direitos Humanos: fundamentos teórico-metodológicos. João Pessoa : Universitária/UFPB, 2006, p. 75

20 De fato, havia certo consenso no plano político e intelectual no sentido de que, desde os governos de Getúlio Vargas, o país vivenciou um amplo e extenso período de promoção de direitos das pessoas (como a sistematização do modelo de proteção trabalhista, com instituição de carteira de trabalho, direito de sindicalização, de assistência social, de aposentadoria, dentre outros). SADER, Emir. "Contexto histórico e educação em direitos humanos no Brasil: da ditadura à atualidade.” SILVEIRA, Rosa Maria Godoy et al. Educação em Direitos Humanos: fundamentos teórico-metodológicos. João Pessoa : Universitária/UFPB, 2006, p. 76

21 Para SADER, esse "pacto" foi a base de sustentação dos governos entre 1930 e 1964. Em particular, cita que "o projeto nacional e popular, defendido pela esquerda e presente no governo de João Goulart, destacava a dimensão econômica, encarregada de arrastar, na sua dinâmica, a promoção dos direitos dos que eram transferidos da situação de informalidade para a de direitos trabalhistas."(Idem, p. 75)

22 SADER, Emir. Contexto histórico e educação em direitos humanos no Brasil: da ditadura à atualidade. SILVEIRA, Rosa Maria Godoy et al. Educação em Direitos Humanos: fundamentos teórico-metodológicos. João Pessoa : Universitária/UFPB, 2006, p. 78 
Bem por isso que, em curto período, vimos o país transitar de um contexto de ampla instabilidade constitucional para um momento de implementação de um peculiar constitucionalismo social, trazido pela Carta de 1988. De certa forma, o fato de se produzir naquele momento político um texto constitucional, permitiu uma influência profunda do processo de internacionalização dos direitos humanos, tanto no texto original da Constituição, como também em algumas das emendas subsequentes. ${ }^{23} \mathrm{Há}$, com isso, um curioso paradoxo na história constitucional brasileira: a sua instabilidade tem permitido que haja uma conjugação dos preceitos de humanização do Direito Internacional com as diretrizes estabelecidas na Constituição vigente de forma mais imediata, sem o necessário processo evolutivo gradual. Sob esse prisma, é realmente espantoso que, em menos de 200 anos como Estado independente, o Brasil tenha uma Carta Constitucional que agrega valores dos mais importantes em matéria de direitos humanos - coisas que Estados muito mais antigos ainda não têm, e outros que os possuem levaram muito mais tempo para obter. ${ }^{24}$

Pelas mesmas motivações, a temática da educação em direitos humanos praticamente inexistia na sociedade brasileira até o período ditatorial militar (19641985). A própria política educacional sofreu diversas variações temporais, dirigidas fundamentalmente por iniciativas isoladas de alfabetização de adultos, em função da grande massa popular sem acesso à educação formal. Algumas campanhas no decorrer dos anos 1940 e 1950 foram dirigidas a esse público, sendo certo que, durante o governo de Juscelino Kubitschek (entre 1955 e 1960) essas campanhas praticamente desapareceram. ${ }^{25}$ Apenas em algumas unidades da federação viam-se atividades ainda remanescentes com essa finalidade.

Uma das iniciativas nesse sentido deu-se a partir do Recife, onde foi criado o Movimento de Cultura Popular (MCP), cujas ações visavam à criação de um plano de alfabetização e educação de base voltadas para crianças e adultos, de forma simultânea. Apesar dos bons propósitos e do relativo êxito dessa atividade, ela não ficou imune às críticas de Paulo Freire, que rejeitava, sobretudo, a iniciativa

23 Nesse sentido, vemos clara a valorização a esses preceitos fundantes e informadores, narrados por Canotilho, desde o preâmbulo constitucional, passando pelo art. $1^{\circ}$. da Carta, e pela inserção do Título relativo aos "Direitos e Garantias Fundamentais" logo no início do texto. Por seu turno, temos no conteúdo do art. $5^{\circ}$. a expressão do que existe de mais substancial em termos de direitos fundamentais, imediatamente seguido dos Direitos Sociais consagrados no Capítulo II do mesmo Título. A influência no Poder Constituinte derivado ainda se revela, por exemplo, com a inserção dos par. $3^{\circ}$. e $4^{\circ}$. feita pela Emenda no. 45/2004, este último tratando do reconhecimento brasileiro da jurisdição de Tribunal Penal Internacional.

24 Além disso, foi a partir dos anos 1990 que o Brasil passou a ratificar a maior parte das convenções e tratados internacionais consagradores de direitos humanos, ingressando, de forma definitiva, no plano global de proteção a esses direitos.

25 FREITAS, Marcos Cezar de e BICCAS, Maurilane de Souza. História Social da Educação no Brasil (1926-1996). Vol. 3. São Paulo : Cortez, 2009, p. 225 
do MCP de publicar um livro/cartilha para servir de material didático. Foi daí que Freire estabeleceu uma proposta de alfabetização implementada em Pernambuco, e que serviu como experiência para que se aplicasse na cidade de Angicos, no sertão do Rio Grande do Norte. Assim, com base na metodologia proposta por Freire, foram alfabetizados 300 trabalhadores em cerca de $45 \mathrm{dias}^{26}$, o que resultou em um convite do Ministro da Educação para expandir seu método para todo o território nacional, mediante a constituição dos chamados Círculos de Cultura em cada um dos Estados federados.

Com isso, iniciou-se uma "campanha de alfabetização em escala nacional que envolvia, nas primeiras etapas, o setores urbanos, e deveria estender-se imediatamente depois dos setores rurais." ${ }^{27}$ Esse trabalho foi completamente abandonado pelo regime que se seguiu ao Golpe de 1964, travando por completo quaisquer iniciativas que pudessem ter como foco uma educação formativa ou emancipatória. Nesse período, todo o sistema educacional foi centrado naquilo que Freire chamaria de educação bancária, bem apropriada para o regime militar que perdudaria por mais de vinte anos.

Se toda a evolução da educação restava interditada pela repressão ditatorial, nem se imaginava falar-se em educação em direitos humanos. Como já dito, somente no curso do regime de exceção - e motivados pelas práticas já citadas - foram surgindo movimentos sociais de reivindicação dessa temática, sobretudo por intermédio das comissões de direitos humanos. ${ }^{28}$ Depois da redemocratização, tornaram-se cres-

26 Essa informação quantitativa é de WEFFORT, Francisco C. (Educação e política - Reflexões sociológicas sobre uma pedagogia da Liberdade. Educação como prática da liberdade - prefácio. Rio de Janeiro : Paz e Terra, 1989, p.11). No entanto, FREITAS, Marcos Cezar de e BICCAS, Maurilane de Souza. (História Social da Educação no Brasil (1926-1996). Vol. 3. São Paulo: Cortez, 2009, p. 239) afirmam que há poucas informações disponíveis sobre os índices de alfabetização em Angicos, havendo estimativas de que foram 77,8\% dos educandos, o que não deixa de ser um número absolutamente surpreendente, para a realidade social daquela localidade, na época em que os fatos ocorreram.

27 Segundo o autor, no período indicado houve cursos de capacitação de coordenadores em quase todas as capitais de Estados, sendo que, para 1964, o projeto previa a instalação de 20.000 Círculos para atendimento de cerca de 2 milhões de alfabetizandos (WEFFORT, Francisco C. Educação e política - Reflexões sociológicas sobre uma pedagogia da Liberdade. Educação como prática da liberdade - prefácio. Rio de Janeiro : Paz e Terra, 1989, p. 11)

28 SADER, Emir. Contexto histórico e educação em direitos humanos no Brasil: da ditadura à atualidade. SILVEIRA, Rosa Maria Godoy et al. Educação em Direitos Humanos: fundamentos teórico-metodológicos. João Pessoa : Universitária/UFPB, 2006, p. 81 
centes as iniciativas institucionais para a inserção do tema em todo o processo, ${ }^{29}$ estando presentes não apenas na Constituição da República, mas também na Lei de Diretrizes e Bases da Educação Nacional (9.394/96). Ao lado disso, em 1996 foi elaborada a primeira versão do Plano Nacional de Direitos Humanos (PNDH), contemplando a preocupação com a educação em direitos humanos, devidamente reprisada nas versões seguintes (2002 e 2006). Por fim, em 2003, lançou-se o Plano Nacional de Educação em Direitos Humanos (PNEDH), fundado sobretudo nas diretrizes internacionais existentes, e cuja função primordial é o estabelecimento de políticas específicas de implantação dos conceitos estruturados desde o primeiro PNDH, especialmente difundindo a cultura de direitos humanos no país, mediante "a disseminação de valores solidários, cooperativos e de justiça social". 30

\section{Criticização e problematização: o sentido freiriano de educação}

Como já situamos, até meados da década de 1960, a agenda político-institucional brasileira estava completamente voltada para a lógica do desenvolvimento, não havendo qualquer preocupação sistemática com a formulação de políticas relacionadas aos direitos humanos. A própria educação, como dito, era centrada na lógica desenvolvimentista, adquirindo um formato que veio posteriormente a ser disseminado pela ditadura militar, ou seja, de valorização da educação enquanto aperfeiçoamento técnico e tecnicista, com menosprezo de seu caráter de formação. ${ }^{31}$ Freire surge trazendo a bandeira da crítica severa desse modelo, que considerava desconectado da realidade brasileira, não se enquadrando nem nas necessidades da sociedade moderna e nas demandas do desenvolvimento. ${ }^{32}$ Embora não

29 Nesse sentido: "O debate sobre direitos humanos e a formação para a cidadania vem alcançando mais espaço e relevância no Brasil, a partir dos anos 1980 e 1990, por meio de proposições da sociedade civil organizada e de ações governamentais no campo das políticas públicas, visando ao fortalecimento da democracia." (BRASIL, Comitê Nacional de Educação em Direitos Humanos. Plano Nacional de Educação em Direitos Humanos. Brasília : Secretaria Especial de Direitos Humanos; Ministério da Educação e Ministério da Justiça; UNESCO, 2006, p. 16)

30 O plano justifica essa disseminação, tendo como pressuposto que "o processo de democratização requer o fortalecimento da sociedade civil, a fim de que seja capaz de identificar anseios e demandas, transformando-as em conquistas que só serão efetivas, de fato, na medida em que forem incorporadas pelo Estado brasileiro como políticas públicas universais.” (Idem, p. 18)

31 Esse assunto seria por ele revisitado em 1969, em escritos publicados dez anos depois sob a denominação Educação e mudança. Segundo GADOTTI, tais textos contêm um "resumo das ideias de Paulo Freite sobre a conscientização e denuncia a visão de mundo tecnicista, economicista e mecanicista que está presente nas reformas sociais e educacionais" (GADOTTI, Moacir. Pensamento Pedagógico Brasileiro. 8 ed. São Paulo : Ática, 2010, p. 39).

32 FREITAS, Marcos Cezar de e BICCAS, Maurilane de Souza. História Social da Educação no Brasil (1926-1996). Vol. 3. São Paulo : Cortez, 2009, p. 227. 
fosse a única voz nesse sentido ${ }^{33}$, Freire se notabilizou exatamente por ter conseguido realizar experiências práticas que comprovaram a superação dos dogmas estruturantes do pensamento hegemônico na ocasião. ${ }^{34}$ Posteriormente, mesmo no exílio, continuou a realizar as atividades educativas, em planos cada vez mais abrangentes, e conseguiu sistematizar suas experiências, sempre a partir de diálogos com amigos e companheiros, e anotam fichas de suas rotinas pedagógicas. ${ }^{35}$

Mas o que significava exatamente essa crítica freireana ao modelo educacional vigente no país, e em que se fundava o seu pensamento de caráter renovador? É assente que Freire era discípulo de Anísio Teixeira, por intermédio de quem adotou concepções pedagógicas escolonovistas, fundadas em John Dewey. ${ }^{36}$ No entanto, essas concepções receberam, em Freire, a influência de seu pensamento religioso, eis que ele era integrante de um grupo da Igreja Católica que começava a constituir a "esquerda" daquela instituição: com fundamento na reorientação da doutrina social da Igreja, instituída por João XXIII, esse grupo estabeleceu o que se nominou solidarismo cristão, que terá, mais adiante, importância fundamental na redemocratização do país, sobretudo pelo desenvolvimento da Teologia da Libertação. ${ }^{37}$ A propósito, a religião e, particularmente, sua interpretação revisitadora, teve um papel substancial na formulação doutrinária de Freire. Não por acaso, já na sua obra inaugural, ele aponta que a religião, que encarna este sentido transcendental das relações do homem, jamais deve ser um instrumento de alienação: "exatamente porque, ser finito e indigente, tem o homem na transcendência, pelo amor, o seu retorno à sua Fonte. Que o liberta. No ato de discernir porque existe e não só vive, e acha a raiz (...) da descoberta de sua temporalidade, que ele começa a fazer precisamente quando (...)reconhece o hoje e descobre o amanhã" ${ }^{38}$

33 FREITAS \& BICCAS noticiam que essa avaliação era compartilhada por nomes de peso como Hélio Jaguaribe e Anísio Teixeira, dentre outros (FREITAS, Marcos Cezar de e BICCAS, Maurilane de Souza. História Social da Educação no Brasil (1926-1996). Vol. 3. São Paulo : Cortez, 2009, p. 22)

34 A referência, naturalmente, evoca a experiência de Freire em Angicos e com os Círculos de Cultura, mencionadas no capítulo anterior.

35 Foi daí surgiu o livro Pedagogia do oprimido, nos dizeres do próprio Freire, "Foi vivendo a intensidade da experiência da sociedade chilena, da minha experiência naquela experiência, que me fazia sempre repensar a experiência brasileira, cuja memória viva trouxera comigo para o exílio, que escrevi a Pedagogia do oprimido, entre 1967 e 1968”. (1992, p. 53)

36 GHIRALDELI JR., Paulo. História da Educação Brasileira. 4ed. São Paulo : Cortez, 2009, p. 107

37 Essa reorientação da doutrina social da Igreja Católica surge a partir das Encíclicas Mater et Magistra (1960) e Pacem in Terris (1962). A primeira, inclusive, é citada expressamente por Freire em sua primeira obra (1989, p. 58, nota 19).

38 FREIRE, Paulo. Educação como Prática da Liberdade. 19 ed. Edição. Rio de Janeiro : Paz e Terra, 1989, p. 40. 
Nesse contexto, encontra-se no pensamento freireano a constatação de que o ser humano tem a vocação natural para ser sujeito da história e não objeto dela, condição na qual teria um papel ativo no processo de transformações sociais. Essas transformações seriam realizadas na própria dinâmica das relações estabelecidas entre os homens, dado o caráter "criador" igualmente inerente à condição humana. No entanto, para alcançar esse estágio, seria fundamental a conscientização, vista não somente como "tomada de consciência" mas também como "consciênção e ação". Em outras palavras, a conscientização é algo que se realiza não somente na teoria, mas sobretudo na práxis, ${ }^{39}$ porque o fato de apenas conhecer o fenômeno confere ao ser humano apenas uma "consciência ingênua" sobre ele; no entanto, a plenitude de sua compreensão do mundo exige a tomada de uma "consciência crítica". ${ }^{40}$

Aqui é que surge, com plenitude, a constatação da relevância do papel da educação. Para Freire, a educação brasileira, até aquele momento, destinava-se somente a preservar o status quo, pois não havia nenhum interesse de nenhum dos governantes ou das elites de permitir qualquer atitude emancipatória das massas populares. Por isso, eram tímidas as iniciativas que visavam à redução do analfabetismo; e o máximo que se via por parte das elites dominantes eram tentativas de acomodação das classes emergentes, com o sentido de sua domesticação. ${ }^{41}$ Daí porque sua crítica era centrada no que nominou de educação bancária: trata-se do modelo em que "a educação se torna um ato de depositar, em que os educantes são os depositários e o educador o depositante".42 A simplicidade dessa metáfora denota toda a sua complexidade: o processo educacional tradicional, atacado por Freire, é configurado por um sistema narrativo, em que o educador é o sujeito, conduzindo os educandos à memorização mecânica do conteúdo narrado. Essa modalidade educacional transforma os educandos em recipientes, a serem enchidos pelo educador, que será considerado melhor tanto mais consiga encher os seus depósitos, que serão qualificados pela sua capacidade de armazenamento de conteúdo. Por isso é que essa educação é opressiva, pois considera o educando alguém totalmente despossuído,

39 GADOTTI, Moacir. Pensamento Pedagógico Brasileiro. 8 ed. São Paulo : Ática, 2010, p. 39

40 FREIRE, Paulo. Educação como Prática da Liberdade. 19 ed. Edição. Rio de Janeiro : Paz e Terra, 1989.

41 WEFFORT, Francisco C. Educação e política - Reflexões sociológicas sobre uma pedagogia da Liberdade. Educação como prática da liberdade - prefácio. Rio de Janeiro : Paz e Terra, 1989, p. 17.

42 FREIRE, Paulo. Pedagogia do Oprimido. Rio de Janeiro : Paz e Terra, 2005, p. 66 
e que está destinado a ser permanentemente depósito dos dogmas do professor. ${ }^{43}$ Estimula, ainda, o mutismo do povo, pois funda-se exclusivamente no verbalismo e na memorização de informações, sem inclusive, se justificar a utilidade dessas informações. Por isso, apenas assistencializa, domestica e inibe a criatividade, por servir à dominação, negando aos homens "sua vocação ontológica e histórica de humanizar-se". ${ }^{44}$

Sua proposta educacional consiste, portanto, em reconhecer que todo ato educativo é um ato essencialmente político, de modo que a educação bancária deve ser substituída por um modelo que permita a cada educando a problematização das situações por ele vivenciadas, a fim de formular a consciência crítica já destacada. A isso ele nomina de educação problematizadora, que, ao contrário da anterior, presta-se à libertação, fundando-se "na criatividade e estimula a reflexão e a ação verdadeiras dos homens sobre a realidade." Com isso, conclui, os homens respondem à sua vocação, "como seres que não podem autenticar-se fora da busca e da transformação criadora", ${ }^{45}$ já que são, naturalmente, seres que estão sendo, ou seja, são seres inconclusos, cientes de sua inconclusão e de seu permanente movimento de busca do ser mais. ${ }^{46}$ Também pelo mesmo motivo, a educação problematizadora reforça a mudança, não aceitando um presente "bem-comportado" nem um futuro pré-dado, enraizando-se no presente dinâmico e fazendo-se revolucionária. ${ }^{47}$

Fundado nesses elementos diferenciais, ele critica, de forma veemente, o modelo educacional vigente e a alienação que provoca, suscitando aquilo que será a essência de todo o seu trabalho: a compreensão do educando como sujeito do ato educacional, e não mero objeto dele:

43 Freire explica, ainda, as características da educação bancária, na qual: “a) O educador é o que educa; os educandos, os que são educados; b) O educador é o que sabe, os educandos, os que não sabem; c) O educador é o que pensa; os educandos, pensados; d) O educador é o que diz a palavra; os educandos os que a escutam docilmente; e) O educador é o que disciplina; os educandos, os disciplinados; f) O educador é o que opta e prescreve sua opção; os educandos, os que seguem a prescrição; g) o educador é o que atua; os educandos, os que têm a ilusão de que atuam, na atuação do educador; h) o educador escolhe o conteúdo programático; os educandos, jamais ouvidos nesta escolha, se acomodam a ele; i) o educador identifica a autoridade do saber com sua autoridade funcional, que opõe antagonicamente à liberdade dos educandos; estes devem adaptar-se às determinações daquele; j) o educador, finalmente, é o sujeito do processo; os educandos, meros objetos.” FREIRE, Paulo. Pedagogia do Oprimido. Rio de Janeiro : Paz e Terra, 2005, p. 68

44 FrEIRE, Paulo. Pedagogia do Oprimido. Rio de Janeiro : Paz e Terra, 2005, p. 83

45 FREIRE, Paulo. Pedagogia do Oprimido. Rio de Janeiro : Paz e Terra, 2005, p. 83

46 Mais uma vez, Freire trabalha com elementos comparativos entre os modelos educacionais para justificar suas opções. Nesse sentido, mostra que esses elementos são valorizados e reconhecidos pela educação problematizadora, mas são ignorados pela educação bancária, que compreende os homens como seres prontos e acabados.

47 FREIRE, Paulo. Pedagogia do Oprimido. Rio de Janeiro : Paz e Terra, 2005, p. 84 


\begin{abstract}
"Pensávamos numa alfabetização direta e realmente ligada à democratização da cultura, que fosse uma introdução a essa democratização. Numa alfabetização que, por isso mesmo, tivesse no homem, não esse paciente do processo, cuja virtude única é ter mesmo paciência para suportar o abismo entre sua experiência existencial e o conteúdo que lhe oferecem para sua aprendizagem, mas o seu sujeito". ${ }^{48}$
\end{abstract}

Tomando-se esse pressuposto, resta rompida a cadeia perversa trazida pela educação bancária, em que a figura do educador tinha precedência sobre a do educando. Do contrário, uma educação focada na problematização pressupõe uma interação completa de ambos, mediante uma ação dialógica, em franca contraposição ao sistema tradicional, focado no antidiálogo. A ação dialógica constitui, assim, um dos princípios da pedagogia freireana e, como ele mesmo define, trata-se da essência da educação como prática da liberdade. ${ }^{49}$ Representa nada menos do que a ação mediadora do processo de conscientização, de problematização e de transformação social, visto que seu oposto (a ação antidialógica) é contra-revolucionário e tende a anestesiar a transformação dos seres humanos e do mundo. ${ }^{50}$ Diálogo é, segundo Freire, “uma relação horizontal de A com B. Nasce de uma matriz crítica e gera criticidade (Jaspers). Nutre-se do amor, da humildade, da esperança, da fé, da confiança". ${ }^{51} \mathrm{E}$, "sem ele não há comunicação e sem esta não há verdadeira educação. A que, operando a superação da contradição educador-educandos, se instaura como situação gnosiológica, em que os sujeitos incidem seu ato cognoscente sobre o objeto cognoscível que os mediatiza". ${ }^{52}$

Esse método dialógico é que permite a construção de uma práxis totalmente voltada para a realidade do educando, que o transforma em pessoa consciente da sua condição de fazedor de um mundo de cultura, apenas pelo fato de se demonstrar

48 Freire faz uma brincadeira com os sentidos diversos da palavra "paciente": para criticar a posição passiva em que se coloca o educando, diz que apenas alguém com muita paciência poderia, após um dia de árduo trabalho, aguentar um aprendizado fundado em realidade completamente alheia à sua. FREIRE, Paulo. Educação como Prática da Liberdade. 19 ed. Rio de Janeiro : Paz e Terra, 1989, p. 104.

49 FREIRE, Paulo. Pedagogia do Oprimido. Rio de Janeiro : Paz e Terra, 2005, p. 89

50 Freire dedica um capítulo inteiro de seu livro para tratar da Teoria da ação antidialógica. Ali, explica que se trata de uma ação intencional e usada para a preservação da dominação e da opressão, que se faz por meio da conquisa paternalista, sutil ou repressora dos oprimidos. Aponta, ainda, as características dessa teoria, que são: a Conquista; Dividir para manter a opressão; a Manipulação e a Invasão Cultural (FREIRE, 2005. p. 157).

51 FREIRE, Paulo. Educação como Prática da Liberdade. 19 ed. Rio de Janeiro : Paz e Terra, 1989, p. 107

52 FREIRE, Paulo. Pedagogia do Oprimido. Rio de Janeiro : Paz e Terra, 2005, p. 96 
a ele que cultura é toda criação humana.$^{53}$ Isso autoriza a identificação do chamado "universo vocabular" do educando, mediante a extração de "palavras geradoras" extraídas de sua própria experiência, o que constitui o ponto de partida do aprendizado: diferentemente da abstração típica da educação bancária, o educando parte da sua realidade empírica para depois de compreendê-la alcançar a abstração generalizante. Nesse processo dialógico-dialético, educador e educando aprendem juntos, à medida da superação das situações limítrofes que são levados a enfrentar em cada etapa do aprendizado, de modo que, ao final, conseguem visualizar todo o seu contexto. ${ }^{54}$

Embora inicialmente estruturados para atender à alfabetização de adultos, especialmente aqueles destituídos de qualquer educação formal, os preceitos consolidados por Paulo Freire em suas obras foram imprimindo matrizes da maior relevância na conformação de um modelo pedagógico singular. Por isso, também foram (e são) usados na alfabetização de crianças e adolescentes e ainda em outros níveis de educação formal, além de permanecerem como instrumentos fundamentais na ampliação do universo de cidadãos alfabetizados.

\section{4 À guisa de conclusão: há educação em direitos humanos em Paulo Freire?}

Conforme já apontamos anteriormente, Paulo Freire não formulou conceitos específicos a respeito dos direitos humanos, nem tampouco realizou formulações voltadas sistematicamente ao que hoje nominamos de educação em direitos humanos. Isso se explica pelas razões históricas já enunciadas nos itens iniciais, particularmente porque a construção originária do seu projeto de alfabetização foi realizada em um tempo em que esse assunto ainda não continha a carga axiológica obtida no final do século XX. No entanto, seria completamente equivocada qualquer análise de sua obra que desconsiderasse um sentido próprio de educação em direitos humanos.

Com efeito, como temos apontado desde a origem, a educação em direitos humanos pressupõe a necessidade de que os cidadãos tomem a efetiva consciência

53 Ou seja, repercutem um conceito antropológico de cultura, segundo o qual "cultura é definida como um conjunto de ideias, valores, crenças, hábitos assimilados desde o nascimento. A cultura, assimilável na ação sobre o mundo estaria à mão porque tudo o que existe na natureza é cultura" (FREITAS, Marcos Cezar de e BICCAS, Maurilane de Souza. História Social da Educação no Brasil (1926-1996). Vol. 3. São Paulo : Cortez, 2009, p. 236).

54 Freire descreve os passos de construção desse aprendizado, que vai desde a elaboração do programa, passando pelos "temas geradores" e pela exploração das contradições, até chegar à última etapa do desenvolvimento dos estudos (FREIRE, Paulo. Pedagogia do Oprimido. Rio de Janeiro : Paz e Terra, 2005, p. 96 e seguintes). 
daquilo que os modelos internacionais e nacionais de proteção aos direitos humanos asseguram a todos, como elementos indispensáveis à sua existência digna. Esse caminho tem se mostrado, senão o único, ao menos o mais eficiente no sentido de se consubstanciar um plano de efetivação para os direitos humanos. Afinal, como exposto, superada a fase de afirmação histórica e reconhecimento institucional dos direitos humanos, a pós-modernidade nos desafia à implementação concreta desses direitos, até mesmo para que não venham a cair no descrédito causado pela sua ineficácia.

Por isso, é inegável a compreensão de que a obra de Paulo Freire foi totalmente construída com esse vetor. Esse referencial aparece, de plano, quando se identifica o paradigma diferenciador da educação bancária, objeto de sua irresignação, com a educação problematizadora, suscitada por ele como sendo instrumento fundamental para a prática da liberdade. Como dissemos, o principal elemento diferencial situa-se na consciência crítica dos educandos construída com o segundo modelo e interditada pelo primeiro. A consciência ingênua, primeiro estágio da consciência dita por ele transitiva, é aquela que

(...)se caracteriza pela simplicidade na interpretação dos problemas. Pela tendência a julgar que o tempo melhor foi o tempo passado. Pela subestimação do homem comum. Por uma forte inclinação ao gregarismo, característico da massificação. Pela impermeabilidade à investigação, a que corresponde um gosto acentuado pelas explicações fabulosas. Pela fragilidade na argumentação.(...) É a consciência do quase homem massa, em quem a dialogação mais amplamente iniciada do que na fase anterior se deturpa e se destorce. ${ }^{55}$

Já a consciência crítica, obtida com uma educação dialogal e ativa, é voltada para a responsabilidade social e política, e se caracteriza exatamente pela prática reversa do que se dá com a que a antecedeu. É, como já explanado, a consciência real, concreta, que se consuma pela práxis, e não apenas por estar situada no plano meramente intelectual. No plano dos direitos humanos, essa consciência é a que opera na vida real do seu sujeito, e o faz não apenas ter a consciência ideal desses direitos, mas sim um ser que efetivamente faz com que eles sejam respeitados. Logo, o simples fato de se educar segundo uma lógica de problematização, já significa praticar a educação em e para os direitos humanos, pois a conformação da consciência transitiva crítica é o elemento substancial para a consagração da sua dimensão efetiva no plano concreto.

Em outro contexto, a linha fundamental da educação freireana tem como foco a liberdade e a emancipação das classes oprimidas, galgadas exatamente pela aqui-

55 FREIRE, Paulo. Educação como Prática da Liberdade. 19a. Edição. Rio de Janeiro : Paz e Terra, 1989, p. 60 
sição da consciência crítica. Com tal processo, Freire acreditava na inserção crítica do povo na história, permitindo-se sua emersão como sujeito histórico, o que, em um primeiro plano, seria elemento gerador da sua libertação e, em seguida, um caminho pavimentado para o processo revolucionário. Afinal, como ele mesmo dizia, "ninguém liberta ninguém; ninguém se liberta sozinho: os homens se libertam em comunhão". ${ }^{56}$ Desse modo, por meio de uma educação problematizadora, que leva à consciência crítica, é possível ampliar-se de forma consistente a participação das massas populares que, organizadas e conscientes, são as mais qualificadas para transformar a sociedade opressora.

Em que pese a ideia original de liberdade, como direito humano, tenha sido fundada em paradigmas eminentemente liberais, sua essência ainda remanesce como uma das principais conquistas contemporâneas, uma vez superados os conceitos limitados como os do laissez-fair; laissez-passer. Naturalmente, por toda a história pessoal, profissional e política de Paulo Freire, não se admite sequer cogitar que ele tinha percepções de ordem liberal ao realizar essas formulações. Sua perspectiva de liberdade está voltada, em primeiro plano, para o rompimento com as amarras da ignorância, usada como instrumento histórico de opressão, por meio da desinformação. Liberdade, para Paulo Freire é, em primeiro lugar, a liberdade para pensar e para ter a capacidade de questionar a ordem das coisas. Como ele diz, “nenhuma 'ordem' opressora suportaria que os oprimidos todos passassem a dizer: 'Por quê?"'.57 Essa liberdade é que conduziria à emancipação dos oprimidos, tornando-os capazes de superar as forças opressoras e situar-se como sujeitos históricos, conforme já explanado. Portanto, aqui se identifica a educação freireana como sendo uma educação para os direitos humanos, pois é notável que a essência de sua proposta é conduzir os cativos à libertação. E não há qualquer dúvida que a liberdade é um dos principais caminhos para se alcançar a efetivação plena dos direitos fundamentais.

De outra parte, a ação dialógica com que trabalha Paulo Freire é também um componente estrutural na educação em direitos humanos. Dialogar representa, de um lado, o exercício da livre manifestação do pensamento, pelo qual cada um exprime aquilo que pretende, ser receio de ser oprimido pelo que manifesta. Mas o diálogo também pressupõe, antes de tudo, o exercício da tolerância, pois não há diálogo se não houver uma atitude de humildade entre os integrantes do processo

56 FREIRE, Paulo. Pedagogia do Oprimido. Rio de Janeiro : Paz e Terra, 2005, p. 58.

57 FREIRE, Paulo. Pedagogia do Oprimido. Rio de Janeiro : Paz e Terra, 2005, p. 87. 
educacional..$^{58} \mathrm{~A}$ atitude dialogal presente na estrutura da educação problematizadora é, portanto, um instrumento fundamental na educação em direitos humanos. Por seu intermédio exercitam-se os direitos de manifestação e o respeito à diversidade, não só das opiniões contrárias mas também aos componentes de ordem cultural trazidos pelos nossos interlocutores. Praticar uma ação dialógica pressupõe a boa fé dos envolvidos na assimilação das particularidades de expressão daqueles com quem se relaciona, de maneira que não se concebe qualquer política educacional em direitos humanos fundada em outros métodos, mormente aqueles nominados de antidialógicos por Freire.

Ainda no que diz respeito à diversidade, enxergamos em Paulo Freire a consagração do respeito às mediações históricas e culturais de cada ser e de cada sociedade, dentro do processo educacional. Ao ter como ponto de partida de sua pedagogia o universo do próprio educando, ele propõe que o aprendizado parta da realidade por ele conhecida, e não daquela estimada pelo educador. Isso tem um profundo sentido de humanização, e destrói qualquer tentativa de antropocentrismo fundada em paradigmas estabelecidos de maneira abstrata e verticalizada. Há um nítido sentido de apoderamento de cada educando, ao atribuir-se a ele o caráter - que lhe é inerente, mas pode não lhe ser conhecido - de um ser fazedor de cultura, em proporções equivalentes àquilo que deriva da indústria cultural que invade a vida de todos nós. O dado interessante desse processo é que, além de servir como método eficiente de aprendizado - eis que parte da realidade sabida, em particular, para aquela desconhecida, de cunho geral - esse sistema tem uma função de extrema relevância na recuperação da dignidade de pessoas que a haviam esquecido. Freire narra experiências práticas que mostram como a retirada de elementos do que ele nominou "universo vocabular" de educandos analfabetos, os transformou não somente no processo de aprendizado, mas como também resgatou sua auto-estima. ${ }^{59}$ Esse bem imaterial tem uma inestimável relevância na compreensão da dimensão humana do ser, e se presta à valorização intrínseca dessa sua inabalável condição.

Com um sentido parecido, identifica-se em Paulo Freire a sua concepção de ser humano, que é qualificado por ele como sendo um ser inacabado, inconcluso. Essa característica faz com que ele seja naturalmente fadado a adquirir novos aprendizados e novas experiências. E, além de ser inacabado, é o único ser vivente que tem

58 “Não há diálogo, porém, se não há um profundo amor ao mundo e aos homens. Não é possível a pronúncia do mundo, que é um ato de criação e recriação, se não há amor que a infunda. (...) Não há, por outro lado, diálogo se não há humildade. A pronúncia do mundo, com que os homens o recriam permanentemente, não pode ser um ato arrogante." (FREIRE, Paulo.

Educação como Prática da Liberdade. 19 ed. Rio de Janeiro : Paz e Terra, 1989, p. 92)

59 FREIRE, Paulo. Educação como Prática da Liberdade. 19 ed. Rio de Janeiro : Paz e Terra, 1989, p. $109 / 110$ 
plena consciência dessa sua condição, o que lhe dá também a vocação natural de ser mais. O que seria, então, o ser mais, de Paulo Freire? Nada menos do que a humanização do homem que, como vocação histórica, o leva a ansiar pela liberdade, pela justiça, pela luta dos oprimidos e pela humanidade roubada e, em síntese, a luta por tudo o que lhe é negado. ${ }^{60} \mathrm{Em}$ outras palavras, ser mais significa lutar pela sua própria dignidade. Se assim é, e sendo a dignidade da pessoa humana o epicentro de todo o sistema de proteção dos direitos humanos, a educação para Paulo Freire é, fundamentalmente, uma educação para os direitos humanos, já que, em última análise, ela se destina a permitir que todos possam ser mais. 


\section{Referências bibliográficas}

ALVES, Rubem. A escola com que sempre sonhei sem imaginar que pudesse existir. 9 ed. Campinas : Papirus, 2006.

ARENDT, Hannah. As origens do totalitarismo. 2 ed. Rio de Janeiro : s.n., 1979.

BITTAR, Eduardo Carlos Bianca. "Educação e metodologia para os direitos humanos: cultura democrática, autonomia e ensino jurídico". SILVEIRA, Rosa Maria Godoy, et al (org). Educação em Direitos Humanos: fundamentos teóricos-metodológicos. João Pessoa : Universitária; UFPB, 2007, p. 313-334.

—. O Direito na Pós-Modernidade. 2 ed. Rio de Janeiro : Forense Universitária, 2009.

BRASIL, Comitê Nacional de Educação em Direitos Humanos. Plano Nacional de Educação em Direitos Humanos. Brasília : Secretaria Especial de Direitos Humanos; Ministério da Educação e Ministério da Justiça; UNESCO, 2006.

BRUTSCHER, Volmir José. Paulo Freire: Direitos humanos, história e liberdade. CARBONARI, Paulo César (org.). Sentido Filosófico dos Direitos Humanos - Leituras do Pensamento Contemporâneo. Passo Fundo : IFIBE, 2006, Vol. 1, p. 113-127.

CANOTILHO, Joaquim José Gomes. Direito Constitucional e Teoria da Constituição. Coimbra : Almedina, 1998.

COMISSÃO Nacional para as Comemorações do 50o. Aniversário da Declaração Universal dos Direitos do Homem. Educação em Matéria de Direitos Humanos e Tratados de Direitos Humanos. Lisboa : Gabinete de Documentação e Direito Comparado da Procuradoria Geral da República de Portugal, 2002.

FREIRE, Lutgardes Costa. Paulo Freire por seu filho. SOUZA, Ana Inês (org.). Paulo Freire - Vida e obra. 2 ed. São Paulo : Expressão Popular, 2010, p. 305-318.

FREIRE, Paulo. A importância do ato de ler em três artigos que se completam. 21a. Edição. São Paulo: Autores Associados; Cortez, 1988.

—. Educação como Prática da Liberdade. 19 ed. Rio de Janeiro : Paz e Terra, 1989.

—. Pedagogia da Autonomia - Saberes necessários à prática educativa. 14 ed. Rio de Janeiro : Paz e Terra, 2000.

—. Pedagogia da esperança: um reencontro com a pedagogia do oprimido. Rio de Janeiro : Paz e Terra, 1992.

—. Pedagogia do Oprimido. Rio de Janeiro : Paz e Terra, 2005.

FREITAS, Marcos Cezar de e BICCAS, Maurilane de Souza. História Social da Educação no Brasil (1926-1996). Vol. 3. São Paulo : Cortez, 2009..

GADOTTI, Moacir. Pensamento Pedagógico Brasileiro. 8 ed. São Paulo : Ática, 2010.

GHIRALDELI JR., Paulo. História da Educação Brasileira. 4 ed. São Paulo : Cortez, 2009.

HARVEY, David. Condição pós-moderna. São Paulo : Loyola, 2001.

LAFER, Celso. A reconstrução dos direitos humanos. São Paulo : Companhia das Letras, 1999.

MOREIRA, Vital. “O Futuro da Constituição.” GRAU, Eros e GUERRA FILHO, Willis Santiago (orgs.).

Direito Constitucional - Estudos em homenagem a Paulo Bonavides. São Paulo : Malheiros, 2001, p. 313-336.

MORIN, Edgar. Os Sete Saberes necessários à Educação do Futuro. 3 ed. São Paulo; Brasília : Cortez; UNESCO, 2001.

PIOVESAN, Flavia. Direitos Humanos e Justiça Internacional. São Paulo : Saraiva, 2006.

PROCURADORIA Geral do Estado de São Paulo. Instrumentos internacionais de proteção dos direitos humanos. São Paulo : Centro de Estudos da PGESP, 1997.

RAMOS, André Carvalho. Teoria geral dos direitos humanos na ordem internacional. Rio de Janeiro : 
Renovar, 2005.

SADER, Emir. "Contexto histórico e educação em direitos humanos no Brasil: da ditadura à atualidade." SILVEIRA, Rosa Maria Godoy et al. Educação em Direitos Humanos: fundamentos teóricometodológicos. João Pessoa : Universitária/UFPB, 2006, pp. 75-83.

SOUZA, Ana Inês (org.). Paulo Freire - Vida e Obra. 2 ed. . São Paulo : Expressão Popular, 2010.

WEFFORT, Francisco C. Educação e política - Reflexões sociológicas sobre uma pedagogia da Liberdade. Educação como prática da liberdade - prefácio. Rio de Janeiro : Paz e Terra, 1989. 